\title{
Perspective of Community Knowledge and Attitude about Human Trafficking
}

\author{
Nadiroh Nadiroh \\ Environmental Education \\ Universitas Negeri Jakarta \\ Jakarta, Indonesia \\ nadiroh@unj.ac.id
}

\author{
Uswatun Hasanah \\ Departement of Family Welfare Education \\ Universitas Negeri Jakarta \\ Jakarta, Indonesia \\ uswatun_hasanah@unj.ac.id
}

\author{
Shahibah Yuliani \\ Department of Social Science Education \\ Universitas Negeri Jakarta \\ Jakarta, Indonesia \\ shahibah-yuliani@unj.ac.id
}

\begin{abstract}
Indonesia is in the first position with the largest number of human trafficking places in the world. In December 2014, number of human trafficking victims are 6.651 people with $92.46 \%$ are children and women, and $82 \%$ are women who have worked at own country and overseas for labor exploitation, while $18 \%$ are men who mostly exploit while working as ship crew to fishing or other laborers. Therefore, this research is important to prevent human trafficking. This research used survey method and obtained empirical data about community's knowledge and attitude about human trafficking case in East Nusa Tenggara, how the difference of knowledge and attitude of community about human trafficking case between men and women and difference of public attitudes about human trafficking among various classification community. The number of samples of the study were 227 respondents who were the head of the family or family members, taken by multistage random sampling. Based on the result of the research, it was found that people's knowledge on human trafficking is still in various categories high, medium and low. Furthermore, when viewed from the gender, the knowledge of man is higher than the woman, on the contrary to the attitude towards the Crime of Trafficking, the woman's attitude is more positive than the man. Thus there needs to be policies and programs integrated in achieving sustainable development goal.
\end{abstract}

Keywords—attitude; community knowledge; human trafficking

\section{INTRODUCTION}

Human trafficking that occurred in Indonesia reached 6,651 people from March 2005 to December 2014 [1]. This number became the largest among other countries where human trafficking occurred in the world. Based on data from IOM, until December 2014, there were 7193 victims identified of human trafficking. Indonesia occupies the first position with the number of 6651 people or about $92.46 \%$ with details; of female victims 950 children and 4888 adult women. While male victims; 166 children and 647 adult men. From that number, there are $82 \%$ are women who have worked inside and outside the country for labor exploitation. While the remaining $18 \%$ are men who experience the majority of exploitation while working as crew to search for fish or other laborers, including in oil palm plantations in West Kalimantan, Sumatra, Papua and Malaysia.

Each of Indonesia's 34 provinces is a source and destination of trafficking, with the most significant source areas being the provinces of West Java, Central Java, East Java, West Nusa Tenggara, East Nusa Tenggara, and Banten. Based on National Project Coordinator International for Migration (IOM) in Indonesia, NTT is a province with the highest number of human trafficking case in Indonesia.

The existence of women to take part in social life in Indonesia has been started since the beginning of the 20th century [2]. Women's role is indispensable in all aspects of community life, so gender equality is the most important factor to implement in all social life in Indonesia. The dominant discourse which states that women need not be economically self-sufficient has been a major cause of women's linkage and poverty. The educational factor has become part of women's economic independence [3]. Indonesia will not be able to reduce poverty if it does not eliminate gender discrimination. Allowing foolishness, poverty and women's pain is the same as preparing for the poor and foolish generation [4].

The United Nations also established a working team called Open Working Group (OWG), which began working on setting up SGDs objectives. They work in 9 sessions. In early March 2014 , the team produced a guide document consisting of 19 focus areas [5].

Trafficking can be defined as the recruitment and transportation of people through fraud and / or coercion for the purpose of exploitation (UNICEF). Further, it is explained that trafficking in persons is an illegal act by a person, directly or indirectly, to encourage citizens of "third world" countries to enter or remain in another country for the purpose of exploiting 
that person by fraud, or coercion or can also exploit the unstable situation of the person [6]. At a global level, trafficking for sexual exploitation is reported more often than the trafficking of persons for forced labor, becoming drug soldiers and drug traffickers [7]. It further discloses that trafficking in persons means recruitment, transferor violence of coercion, abduction, fraud, abuse of power or acceptance of payments or gain of gain by the control of others, for the purpose of exploitation, which where such exploitation includes to prostitute others or other forms of sexual exploitation, forced labor or service, slavery or similar practices of slavery, servitude or the taking of organs [8]. The elements of human trafficking include three main elements: exploited as labor (prostitutes, rough labor, slavery), smuggling of victims (through recruitment, illegal transport, and / or acceptance), and coercion (achieved through fraud, violence, or threat) [9].

Knowledge is also defined as the ability to think in an active learning process, which includes a chronological thinking process, comprehensive by looking at historical facts, the ability to analyze and interpret a phenomenon, and the ability to make decisions based on evidence against the information obtained. Knowledge is the domain that exists in one's cognitive abilities, therefore it will be discussed what it is and how one is cognitive abilities [10].

The objective of this research was to finding out community's knowledge and attitude about human trafficking case in East Nusa Tenggara, this research took place while increasing the number of people trade cases continue, so it is important to do control and prevention efforts through community understanding about people trade starting from the mapping of how the level of public understanding about people trade.

\section{Methodology}

This research is extracting information about how knowledge and attitude of community to people trade in East Nusa Tenggara (NTT) Region, also exploring inferential quantitative data about difference of knowledge and attitude of community to people trade, between male and female community. Survey method was used in this research. Quantitative data in the form of community knowledge is measured by the test, attitude is measured by scale, while the qualitative data are explored and assessed through FGD (Focus Group Discussion) with guidelines for structured and open interviews. The number of samples were 227 respondents. For reliability test of variable reliability has value $r=0.812$, meaning knowledge instruments used have high reliability. For reliability test of attitude variable also has value of $r=0,949$, meaning that instrument attitude used have high reliability. Quantitative research was analyzed descriptively with percentage and inferential with $\mathrm{F}$ test, while qualitative data was analyzed narratively and inter subjectivity.

\section{RESULTS AND DISCUSSIONS}

The results of this study to describe qualitatively and quantitatively in accordance with the formulation of this research problem are: (1) How does the knowledge and attitude of human trafficking in community of NTT Region based on survey? (2) How does the difference of knowledge and attitude of community to human trafficking between men and women based on survey? (3) How does the difference of knowledge and attitude of community to human trafficking between among various classification of certain community by FGD?

\section{A. Differences the Knowledge about People Human Trafficking Based on Gender}

The level of community knowledge about people trade between male and female respondents is different from $\mathrm{F}$ cal = 3.935 at Sig. $=0.048$.

\section{B. Differences of Attitude about Human Trafficking Based on Gender}

Community attitude about people trade, between male and female respondents is different but not significant with value of Fcal $=0,274$ at Sig. $=0,601$.

\section{Society Knowledge with Special Category}

This research also collects data from some community leaders who represent the community in the region. The results of the analysis of the level of understanding of community leaders are as listed in the table 1.

TABLE I. FOCUS GROUP DISCUSSION RESULTS IN ALL VILLAGES IN NTT (QUANTITATIVE DATA)

\begin{tabular}{|c|l|l|l|}
\hline \multirow{2}{*}{ No } & & \multicolumn{2}{|c|}{ Knowledge of People Trade } \\
\cline { 3 - 4 } & & $\begin{array}{c}\text { Knowledge } \\
\text { Avarage Score }\end{array}$ & $\begin{array}{c}\text { Attitude } \\
\text { Avarage Score }\end{array}$ \\
\hline 1 & Village Devices & 61,80 & 86,87 \\
\hline 2 & Neighborhood Association & 62,17 & 82,50 \\
\hline 3 & Citizens Association & 61,94 & 91,63 \\
\hline 4 & Youth & 63,86 & 75,71 \\
\hline 5 & Women figures & 83,00 & 112,00 \\
\hline 6 & Religious figures & 63,83 & 81,67 \\
\hline 7 & Victim & 56,75 & 85,50 \\
\hline 8 & Village Heads & 62,50 & 87,00 \\
\hline 9 & Traditional figures & 85,17 & 112,50 \\
\hline 10 & Students & 53,50 & 86,00 \\
\hline 11 & Parents & 58,29 & 89,14 \\
\hline
\end{tabular}

Based on the data in Table 1 it can be seen that both the knowledge and the attitudes of the community towards the people trade, the women figures and traditional figures (besides religious figures women female figures) who become role models in their regions have higher average scores compared to other groups. This is in contrast to the level of understanding of people trade's in village device including village heads.

Furthermore, if viewed from each district, South Central Timor regency, especially Tetaf and Tabplo villages have the lowest level of knowledge compared to other districts, the average score of knowledge about people trade is 56.56 with a minimum score of 41 and a maximum knowledge score of 77. Meaning level of knowledge of South Central Timor community in the medium category. 
TABLE II.

DATA DESCRIPTION OF KNOWLEDGE COMMUNITY ABOUT HUMAN TRAFFICKING EACH REGENCY

\begin{tabular}{|l|l|l|l|l|l|l|}
\hline No & \multicolumn{1}{|c|}{ Regency } & N & $\begin{array}{c}\text { Std. } \\
\text { Dev. }\end{array}$ & Mean & $\begin{array}{c}\text { Min } \\
\text { Score }\end{array}$ & $\begin{array}{c}\text { Max } \\
\text { Score }\end{array}$ \\
\hline 1 & Kupang & 125 & 4.992 & 63,67 & 46 & 86 \\
\hline 2 & South Central Timor & 102 & 10,135 & 56,56 & 41 & 77 \\
\hline
\end{tabular}

When viewed from the percentage of the mastery of community knowledge about people trade in East Nusa Tenggara, Kupang has a higher level of knowledge compared to South Central Timor. Overall, South Central Timor district is the district with the lowest level of people trade knowledge. The villagers of Mariance and Naikolan in Kota Kupang have a percentage of knowledge of $78.3 \%$, meaning that they are generally aware of the presence of people trade but people do not know that it is against the people trade around it but has been able to suspect that there is a tendency people trade.

TABLE III. COMMUNITY KNOWLEDGE SCALE ABOUT HUMAN TRAFFICKING

\begin{tabular}{|l|l|l|l|}
\hline \multirow{2}{*}{ No. } & \multirow{2}{*}{ Indicators } & \multicolumn{2}{|c|}{ Regency } \\
\cline { 3 - 4 } & & South Central Timor & Kupang \\
\hline 1 & Process & $70.9 \%$ & $66.9 \%$ \\
\hline 2 & Way & $72.5 \%$ & $68.3 \%$ \\
\hline 3 & Objective & $69.0 \%$ & $88.5 \%$ \\
\hline 4 & Mode & $65.4 \%$ & $81.1 \%$ \\
\hline 5 & Form & $74.4 \%$ & $86.7 \%$ \\
\hline \multicolumn{2}{|l|}{ Average } & $\mathbf{7 0 . 4 \%}$ & $\mathbf{7 8 . 3 \%}$ \\
\hline
\end{tabular}

From some indicators that measure community's knowledge in NTT about people trade, it can be seen that South Central Timor is a district with a higher percentage of knowledge about the higher people trade process of $70.9 \%$ in Two Villages (Tetaf and Taboplo Villages) compared to other areas in NTT. This means that the people of Tetaf and Taboplo villages are not aware that the recruitment process undertaken by individuals is a legal process, but they are already suspecting something is not right in the recruitment. They already suspect something is not right in the recruitment.

How to recruit in the form of persuasion, threats, violence, debt bondage with various to potential victims is something that must be realized and understood by the community so that community can avoid people trade [11]. Various objectives conducted by perpetrators trade in ensnare the victim who all are looking for personal gain and his group by harming the community, especially the victim. Basically, the goal of people trade is to draw the maximum profits [12]. This means that the people of Permanent and Taboplo villages do not know that what the traffickers do is to ensnare them for profit. However, they can suspect that what the traficker does is not true. In contrast, the people in Kupang City are the people who actually know the purpose of people trade done by the person compared with the people in other regencies with the percentage of $85.5 \%$ (position on the scale of 3.42). Based on the table of public attitudes toward people trade, the attitude average score of the community towards people trade in NTT can be seen in Table 4 and 5 below. The highest average score of the attitudes among the regencies and cities is Bogor, while the lowest is Kupang and South Central Timor.
TABLE IV. DATA DESCRIPTION OF ATTITUDE COMMUNITY ABOUT HUMAN TRAFFICKING EACH REGENCY

\begin{tabular}{|l|l|l|l|l|l|l|}
\hline No & \multicolumn{1}{|c|}{ Regency } & N & $\begin{array}{c}\text { Std. } \\
\text { Dev. }\end{array}$ & Mean & $\begin{array}{c}\text { Min } \\
\text { Score }\end{array}$ & $\begin{array}{c}\text { Max } \\
\text { Score }\end{array}$ \\
\hline 1 & Kupang & 125 & 6,218 & 79,06 & 66 & 104 \\
\hline 2 & $\begin{array}{l}\text { South Central } \\
\text { Timor }\end{array}$ & 102 & 6,945 & 79,06 & 52 & 97 \\
\hline
\end{tabular}

Based on the data in Table 4, it can be seen that Kota Kupang and South Central Timor (Tetaf and Taboplo Outbreak) have an average attitude $=79.06$. Community attitudes are measured by several indicators of emotional feeling to accept or reject the occurrence of people trade, the tendency to act in a preventive way against people trade, procedural tendencies / legal steps against people trade. Here is a presentation of community attitudinal data based on some of the indicators in Table. 5.

TABLE V. DESCRIPTION OF COMMUNITY ATTITUDE DATA ABOUT HUMAN TRAFFICKING BY INDICATOR

\begin{tabular}{|l|l|l|l|}
\hline \multirow{2}{*}{ No } & \multicolumn{2}{|c|}{ Indicators } & \multicolumn{2}{c|}{ Regency } \\
\cline { 3 - 4 } & & $\begin{array}{c}\text { South Central } \\
\text { Timor }\end{array}$ & Kupang \\
\hline 1 & Emotional feeling to accept/reduce & $75.4 \%$ & $88.3 \%$ \\
\hline 2 & $\begin{array}{l}\text { The tendency to act in a Preventive } \\
\text { manner }\end{array}$ & $70.8 \%$ & $88.1 \%$ \\
\hline 3 & The tendency to use legal steps & $87.8 \%$ & $89.5 \%$ \\
\hline \multicolumn{2}{|l|}{ Rata-Rata } & $\mathbf{7 8 . 0 \%}$ & $\mathbf{8 8 . 6 \%}$ \\
\hline
\end{tabular}

Viewed from the three indicators used as a reference to measure the attitude of the community that is emotional feeling to accept or reject the people trade, the tendency to act in a preventive way against people trade, and the tendency to act against people trade.

\section{CONCLUSION}

The conclusion of this research is Society knowledge and attitude about Human Trafficking is still in low and medium category. People's perspective from male gender, human trafficking scores are higher than women. As for the attitude towards human trafficking, more positive women reject Human Trafficking than men. So that there is a significant effect of interaction between gender and knowledge on public attitudes about Human Trafficking

\section{REFERENCES}

[1] International Organization for Migration, Perdagangan Manusia available at: https://indonesia.iom.int/id, 2014

[2] A. S. Moertiningsih, Policy Implication of Age-Structural Changes, Paris : Committe for International Cooperation in National Research in Demography. Retrieved from:http://www.cicred.org/Eng/Publications/pdf/Policypapers/pp1.pdf. 2005 .

[3] King, E. M., Change in the Status of Women Across Generation in Asia, 1986, California: The RAND, 2010.

[4] Caldwell, J. C., Demographic Transition Theory, Dordrecht: Springer, 2006.

[5] J. Cornforth, J. Becuwe and U. Sconfienza, SDG's Focus Areas: Stakeholder Proposals for Goals and Targets. 
https://debategraph.org/Stream.aspx?nid=407790\&vt=ngraph \&dc=focus 2014.

[6] P. L. Dudley and M. Micklin, Handbook of Population, New York: Kluwer Academic. 2005.

[7] A. T. Gallagher, The International Low Human Traficking. UK: Cambridge University Press. 2014

[8] S. Cameron and E. Newman, Trafficking in Humans: Social, Cultural and Political Dimensions. United Nations University Press. 2010
[9] Albanese, J. S., "Developing an Agenda for International Criminal Justice Teaching and Training." Publication Series-European Institute For Crime Prevention And Control 53, 2008, 227.

[10] Bloom, D. E., D. Canning, J. Sevilla, The Demographic Dividend-A New Perspective on The Economic Consequences of Population Change, RAND : Netherland. 2002.

[11] Siegel, J. S., and David, A. S., The Methods and Material of Demography, 2nd Edition. London: Elsevier Academic Press, 2004.

[12] Bobadilla, J. L., Loraine, S., Javier, A., Famility Formation Pattern and Child Mortality in Mexico, Demographic and Health: Mexico. 1990. 